\title{
Causes Of Male Dropout Rate In Pakistan
}

\author{
Muhammad Naseer Ud Din, IER, Kohat University, Pakistan \\ Hukam Dad, NUML University Islamabad, Pakistan \\ Javid Iqbal, IER, Karakoram International University-Gilgit, Pakistan \\ Syed Shafqat Ali Shah, IER University of Gujarat, Pakistan \\ Muhammad Imran Niazi, UIER, PMAS Arid Agriculture University, Pakistan
}

\begin{abstract}
This study aimed to seek the cause of male students' dropout rate at the primary level of F.R. Peshawar. The main objectives of the study were: 1) to study the teacher problems and attitudes of the dropouts, 2) to determine the factors that cause dropouts, 3) to study the government's strategy of dropouts, and 4) to provide suggestions to overcome this problem and improve the literacy rate. The simple random sampling technique was used and the researchers selected ten schools of F.R. Peshawar Asho khel. The research study was descriptive in nature. Three types of questionnaires were prepared - one for teachers, one for students, and one for parents. The researcher then collected data, tabulated, analyzed, and interpreted it in a percentage method. On the basis of analysis, it was concluded that the majority of teachers viewed themselves as being responsible for dropouts due to corporal punishment and poor attention given to the students. The majority of students opined that they themselves are responsible for dropping out due to fear of teachers, failure of examinations, mental weaknesses, and being weak in math and English. The majority of parents viewed that they are responsible for their children's dropping out due to their poverty, illiteracy, and unawareness of the importance of education. The following recommendations were made for improvement of the teaching-learning situation in primary education institutions: 1) Teachers should show fair attitudes and behave well; 2) The government should appoint talented and local teachers in the area; 3) Teachers may improve and provide a variety of motivation techniques in different teaching situations; 4) The government should provide full attention to their education system by providing financial support to poor students in the form of scholarships; and 5) The government should facilitate the teachers and increase their salaries.
\end{abstract}

Keywords: Causes of Dropout; Primary level; Government schools; Teachers; Students; Parents

\section{INTRODUCTION}

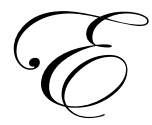

ducation is a need of every society, and society uses school as its agent of socialization. Pakistan is still behind in the race/run of education and cannot improve its literacy rate. It has one of the lowest literacy rates among Asian countries (Farooq, 2001). Our educational system of primary and secondary levels has a very high percentage of students who drop out before completing a particular cycle. Pakistan is the second lowest country among those considered whose students complete their primary education. A high dropout rate marks all levels of primary education and a fairly large number of enrolled students at the primary education level never complete the cycle of their education (Rauf, 1996).

According to Aggrwal (2000), education is a cornerstone of development. It has been proven that education helps in the development of people's position and status in society, which positively impacts employment, earnings, productivity, health, control over population growth, and the literacy rate. Every government has made efforts to promote their literacy rate but failed. Causes include poverty, educational facilities, lack of funding, curriculum, unskilled teachers, criteria for admission, method of teaching, education system, corruption, instability of government, dual system of education and political environment, etc. It is not only a big problem in Pakistan, but also in underdeveloped countries (Sultana 1998). According to the national education policy documents (19982010), the literacy rate was expected to rise from 39\% to 55\% in the first five years and to reach $70 \%$ by 2010. 
Most of the people of this area are drivers, and naturally the students adopt their parental professions. The literacy rate of F.R. Peshawar is $52.76 \%$ for males and $5.26 \%$ for females, with an overall rate of $29.31 \%$, which is very low compared to other areas of FATA.

The measure used to qualify a person as being literate is debatable; one defines that a person who can write his name is literate (Mahmooda, 1999).

According to national policy (1998), education is a powerful catalyzing agent that provides mental, physical, ideological, and moral training to an individual to enable him to have full consciousness of his purpose in life and equip him to achieve that purpose. It is an instrument for spiritual development as well as for material fulfillment of human needs (Shahid, 1999).

Elementary education is the earliest program of education, generally beginning at the age of five or six and lasting six to eight years. The greatest number of any country's population attends the primary stage, which is the means by which universally gifted children can be found. The elementary stage produces the bulk of skilled and literate workers, and a modern technological society can be developed and maintained only when these skilled and literate workers are regularly produced in large numbers. This stage is very important, especially in a democratic society. A democratic government requires that its citizens should be intelligent enough to understand the manifestoes of several political parties to intelligently and critically interpret news and to cast their vitas according to their own free choice and will (Rasool, 2000).

\section{Statement of the Problem}

Statement of the problem of this study was to determine the causes of dropouts at the primary level $\left(5^{\text {th }}\right.$ class) in F.R. Peshawar (male school) and provide information and suggestions to remove hurdles in this area.

\section{Objectives of the Study}

The main objectives of the study were: 1) to study teacher problems and attitudes of dropouts and 2) to determine the factors that cause children to drop out.

\section{Significance of the Study}

Significance of the study is that there is a high dropout rate in all levels of primary and secondary education. A fairly large number of students do not complete their education cycle. The study has great significance because it provides basic and comprehensive information to assist teachers and educational authorities. It provides basic information to the curriculum planner to plan the curriculum according to the needs of teachers and students in hope of overcoming these causes.

\section{Hypotheses of the Study}

Formulations of hypotheses were factors that increase the dropout rate at the elementary level, leaving them without completing their education. Therefore, the following research hypotheses occurred: 1) Students leave school due to poverty, 2) Many students leave school due to a hard and non-flexible curriculum, and 3) Many students leave school due to corporal punishment.

\section{Delimitations of the Study}

Due to limited time and resources, the study was delimited to ten male schools in the F.R. Peshawar Asho Khel area. 


\section{RESEARCH METHODOLOGY}

\section{Nature of the Research}

Research was of the descriptive survey type. Researchers surveyed the government schools of F.R. Peshawar and tried to determine the main cause of dropouts in the $5^{\text {th }}$ class. The level of dropouts in government schools is very high, which is why the literacy ratio in the area is very low. All primary/elementary schools are considered, including the $5^{\text {th }}$ class of F.R. Peshawar.

\section{Sampling}

Although there are many schools in F.R. Peshawar, the researchers limited their studies to ten selected boys' schools located in the area of Asho khel because most of the schools are difficult to reach.

\section{Research Instrument}

The following research instruments were used for the collection of data: 1) Questionnaire A for teachers of government high schools (male), 2) Questionnaire B for parents, and 3) Questionnaire C for students.

\section{Data Collection}

The researcher's data collection process took three or four days of visiting each sampled school and administering the questionnaires in person, then collecting the questionnaires from the teachers, students and parents. The response rate was 100 percent.

\section{Data Analysis}

The researcher arranged the data in a systematic way and organized it in table form. After tabulation, the researcher analyzed the data and expressed it in percentages.

Table 1: Responses of Teacher, Students and Parents

\begin{tabular}{|c|c|c|c|c|c|c|}
\hline S.No & Statements & Responses & $\begin{array}{c}\text { Yes } \\
\text { Percent }\end{array}$ & $\begin{array}{c}\text { No } \\
\text { Percent }\end{array}$ & $\begin{array}{c}\text { Cumulative } \\
\text { Percent }\end{array}$ & Differences \\
\hline \multirow{3}{*}{1} & \multirow{3}{*}{ No full attention of the teacher } & Teachers & $14 \%$ & $86 \%$ & $100 \%$ & $-71 \%$ \\
\hline & & Students & $23 \%$ & $77 \%$ & $100 \%$ & $-54 \%$ \\
\hline & & Parents & $47 \%$ & $53 \%$ & $100 \%$ & $-5 \%$ \\
\hline \multirow{3}{*}{2} & \multirow{3}{*}{ Having a bad society } & Teachers & $95 \%$ & $5 \%$ & $100 \%$ & $89 \%$ \\
\hline & & Students & $31 \%$ & $69 \%$ & $100 \%$ & $-38 \%$ \\
\hline & & Parents & $93 \%$ & $7 \%$ & $100 \%$ & $85 \%$ \\
\hline \multirow{3}{*}{3} & \multirow{3}{*}{ Poverty of the parents } & Teachers & $79 \%$ & $21 \%$ & $100 \%$ & $59 \%$ \\
\hline & & Students & $82 \%$ & $18 \%$ & $100 \%$ & $64 \%$ \\
\hline & & Parents & $61 \%$ & $39 \%$ & $100 \%$ & $22 \%$ \\
\hline \multirow{3}{*}{4} & \multirow{3}{*}{ Oldest method of teaching } & Teachers & $60 \%$ & $40 \%$ & $100 \%$ & $20 \%$ \\
\hline & & Students & $38 \%$ & $63 \%$ & $100 \%$ & $-25 \%$ \\
\hline & & Parents & $81 \%$ & $19 \%$ & $100 \%$ & $62 \%$ \\
\hline \multirow{3}{*}{5} & \multirow{3}{*}{ Corporal punishment } & Teachers & $30 \%$ & $70 \%$ & $100 \%$ & $-40 \%$ \\
\hline & & Students & $74 \%$ & $26 \%$ & $100 \%$ & $48 \%$ \\
\hline & & Parents & $65 \%$ & $35 \%$ & $100 \%$ & $30 \%$ \\
\hline \multirow{3}{*}{6} & \multirow{3}{*}{ Lack of facilities } & Teachers & $76 \%$ & $24 \%$ & $100 \%$ & $52 \%$ \\
\hline & & Students & $61 \%$ & $39 \%$ & $100 \%$ & $21 \%$ \\
\hline & & Parents & $68 \%$ & $32 \%$ & $100 \%$ & $36 \%$ \\
\hline
\end{tabular}




\section{RESULTS AND DISCUSSION}

There were three questionnaires - one for teachers, one for students, and one for parents. Each questionnaire was provided with only two responses - "YES" and "NO". The questions were tabulated to find the percentage of causes of dropouts. The researcher used simple and easy techniques (percentage/\%) to study the behaviors and attitudes of the respondents as shown in Table 1.

Overall responses of teachers, students, and parents are clearly indicated:

1. The first item in the table indicates that $14.28 \%$ of the teachers are in agreement that "no full attention of the teacher" is the cause of dropouts and $85.71 \%$ do not agree, while $23.07 \%$ of the students agree and $76.92 \%$ do not. In the case of parents, $47.36 \%$ agree while $52.63 \%$ do not agree. Overall, $25 \%$ agreed and $75 \%$ did not.

2. In the category of "having a bad society", $94.59 \%$ of the teachers agree that this is the cause of dropouts and $5.40 \%$ do not agree, while $31.24 \%$ of students agree and $68.75 \%$ do not. In the case of parents, $92.59 \%$ agree and $7.40 \%$ do not agree. Overall, $81.25 \%$ agree and $18.75 \%$ do not.

3. "Poverty of the parents" draws a picture that $79.41 \%$ of the teachers admit that this is the cause of dropouts and $20.58 \%$ do not agree, while $82.14 \%$ of students agree and $17.85 \%$ do not. In the case of parents, $61.11 \%$ agree while $38.88 \%$ do not agree. Overall, $76.85 \%$ agree and $23.75 \%$ do not.

4. The methodology of teaching is the most important factor that affects teaching. The results show that $60 \%$ of the teachers agree that "oldest method of teaching" is the cause of dropouts and $40 \%$ do not agree, while $37.50 \%$ of students agree and $17.85 \%$ do not. In the case of parents, $80.76 \%$ agree while $19.24 \%$ do not. Overall, $60 \%$ agree and $40 \%$ do not agree.

5. In the case of "corporal punishment" being the major cause of dropouts at the primary level, it is clear from the table that $30 \%$ of the teachers agree and $70 \%$ do not agree, while $74.07 \%$ of students agree and $25.92 \%$ do not. In the case of parents, $65.21 \%$ agree while $34.79 \%$ do not agree. Overall, $55 \%$ agree and $45 \%$ do not.

6. As for "lack of facilities" being the key cause of dropouts at the primary level, $76 \%$ of the teachers agree and $24 \%$ do not agree, while $60.60 \%$ of students agree and $39.40 \%$ do not. In the case of parents, $68.18 \%$ agree while $31.82 \%$ do not agree. Overall, $67.50 \%$ agree and $32.50 \%$ do not.

\section{CONCLUSIONS}

As a result of these findings, the researcher made the following conclusions about the male students' dropout rate at the elementary level in F.R. Peshawar. Teachers, students and parents were of the view that the dropout problem was due to:

1. The majority of teachers viewed that they were responsible for dropouts because of corporal punishment and poor attention toward the students. Unawareness can also cause students to drop out.

2. The majority of students opined that they themselves are responsible for dropouts because of fear of their teachers, failing of examinations, mental weaknesses, and being weak in math and English. Overplaying is also a cause of dropouts.

3. The majority of parents viewed that they are responsible for their children dropping out because of their poverty, illiteracy, unawareness of the importance of education, having no father at home, and having no full control of their children, which is the responsibility of parents.

\section{RECOMMENDATIONS}

The researcher made the following recommendations for the betterment of students' dropout rate at the elementary level in F.R. Peshawar Asho Khel:

1. Study results revealed that teachers were responsible for dropouts due to corporal punishment. It is recommended that teachers should show fair attitudes and behave well. The government should appoint talented and local teachers in the area. 
2. Study results showed that teachers were responsible for dropouts due to poor attention toward the students. Therefore, it is recommended that teachers should pay full attention to the students by providing incentives, such as rewards. Teachers should improve and provide a variety of motivational techniques in different teaching situations.

3. Study results revealed that students were self-responsible for dropping out due to fear of their teachers, failing of examinations, mental weaknesses, and being weak in math and English. It is recommended that teachers should provide awareness of education to their students by developing faith and confidence. They should also provide a peaceful atmosphere.

\section{AUTHOR INFORMATION}

Dr. Muhammad Naseer-Ud-Din is working as an Assistant Professor in Institute of Education and Research, Kohat University of Science and Technology, Kohat, Pakistan. He did his Ph.D. in Education from University Institute of Education and Research, UAAR, Pakistan.

Dr. Hukam Dad is working as an Assistant Professor in Department of Education, National University of Modern Language, (NUML) Islamabad - Pakistan. He did his Ph.D. in Education from University Institute of Education and Research, UAAR, Pakistan.

Dr. Javid Iqbal is working as an Assistant Professor in Department of Education, Karakoram international University, Gilgit - Baltistan - Pakistan. He did his Ph.D. in Education from University Institute of Education and Research, UAAR, Pakistan.

Dr. Syed Shafqat Ali Shah is working as an Assistant Professor in Institute of Education and Research, University of Gujarat, Pakistan. He did his Ph.D. in Education from University Institute of Education and Research, UAAR, Pakistan.

Dr. Muhammad Imran is working as Secondary School Teacher in Department of Education, Govt. of Punjab School Wing, Pakistan. He did his Ph.D. in Education from University Institute of Education and Research, UAAR, Pakistan.

\section{REFERENCES}

1. Agerwal, J.C. (2000). Theories and principal of education. New Dehli, Viikas Publishing.

2. $\quad$ Rauf Abdur. (19966). Planning for Education in Pakistan Cambrige. Haward University Press.

3. Mahmooda, R. (1999). Curriculum Development." Peshawar, Ijaz Printer Khyber Agency.

4. Shahid S.M (1999). Educational administration. ( $1^{\text {st }}$ edition)" Majeed book depot Lahore. Education policy. Islamabad, 1992.

5. Sultana, N. (1998) Educational Management and supervision Rawalpindi. AIOU Islamabad - Pakistan.

6. Rasool, M.G. (2000). Teacher Education.” Islamabad. Rohani Art Press.

7. Farooq, R.A. (2001). Understanding Research in education”. Rawalpindi. IER Arid Agriculture University. 


\section{NOTES}

